\title{
Method of capture and population structure of Aegla georginae Santos and Jara, 2013 (Decapoda: Anomura: Aeglidae) in a tributary of the Ibicuí River in southern Brazil
}

\author{
C. E. Copattia*, R. P. Legramanti ${ }^{b}$, A. Trevisan ${ }^{c}$ and S. Santos ${ }^{b}$ \\ aPrograma de Pós-graduação em Diversidade Animal, Instituto de Biologia, Universidade Federal da Bahia - UFBA, \\ Campus de Ondina, Rua Barão de Geremoabo, 147, CEP 40170-290, Salvador, BA, Brazil \\ bPrograma de Pós-graduação em Biodiversidade Animal, Universidade Federal de Santa Maria - UFSM, \\ Avenida Roraima, 1000, Cidade Universitária, Camobi, CEP 97105-900, Santa Maria, RS, Brazil \\ 'Departamento de Ciências Biológicas, Universidade Alto Vale do Rio Do Peixe - UNIARP, \\ Rua Victor Baptista Adami, 800, Centro, CEP 89500-000, Caçador, SC, Brazil \\ *e-mail: carloseduardocopatti@yahoo.com.br
}

Received: May 16, 2015 - Accepted: July 28, 2015 - Distributed: November 30, 2016

(With 4 figures)

\begin{abstract}
In the current study, we investigated population aspects of Aegla georginae in the Ibicuí River Basin by considering different capture methods and the implication of these data in the analysis of population dynamics. We sampled 1774 individuals: 1259 males (21 and 97 juveniles and 1029 and 113 adults in trap and handnet, respectively), 512 females ( 05 and 140 juveniles, 184 and 64 adults, and 81 and 38 ovigerous in trap and handnet, respectively) and 03 unsexed individuals (02 and 01 in trap and handnet, respectively). The frequency distribution in size classes shows a bimodal model for both sexes. The carapace length (CL) in males and females varied from 3.11 to 26.00 and 3.73 to $22.36 \mathrm{~mm}$, respectively. Males presented significantly larger sizes than females. The relative abundance between males and females was significantly different from 1:1 with more males than females in most sampling periods $(\mathrm{p}<0.05)$ when considering the grouped data (handnet + trap) and trap captures, but followed the expected ratio in most months when considering individuals sampled only with handnet $(\mathrm{p}>0.05)$. Juveniles were recorded in all seasons, and reproduction occurs throughout the year. The population structure is similar to the model known for aeglids, and the capture methods affected the analysis of $A$. georginae, where the grouped data and trap captures presented greater abundance of individuals than handnet and males predominate in the larger size classes, and females in the intermediary size classes. Therefore, an integrated view of the capture methods is the best model for studying the population dynamics of aeglids.
\end{abstract}

Keywords: carapace length, frequency distribution, relative abundance, reproductive period, aeglids.

\section{Método de captura e estrutura populacional de Aegla georginae Santos and Jara, 2013 (Decapoda: Anomura: Aeglidae) em um afluente do rio Ibicuí no sul do Brasil}

\section{Resumo}

No presente estudo, nós investigamos aspectos populacionais de Aegla georginae na Bacia do rio Ibicuí e consideramos a implicação de diferentes métodos de captura na análise dos dados de dinâmica populacional. Foram amostrados 1774 indivíduos: 1259 machos (21 e 97 juvenis e 1028 e 113 adultos em armadilhas e rede de mão, respectivamente), e 512 fêmeas (05 e 140 juvenis, 184 e 64 adultos, e 81 e 38 ovígeras em armadilhas e rede de mão, respectivamente) e 03 não-sexados (2 e 1 em armadilhas e rede de mão, respectivamente). A distribuição de frequência nas classes de tamanho mostrou um modelo bimodal para ambos os sexos. O comprimento da carapaça (CC) em machos e fêmeas variou de 3,11 a 26,00 e 3,73 a 22,36 mm, respectivamente. Machos apresentaram-se significativamente maiores que as fêmeas. A abundância relativa entre machos e fêmeas foi diferente significativamente de 1:1 com mais machos do que fêmeas na maioria dos períodos amostrados $(\mathrm{p}<0,05)$ quando considerados os dados agrupados (rede de mão + armadilhas) e somente armadilhas, mas seguiu a razão esperada na maioria dos meses quando considerados apenas os indivíduos capturados com rede de mão $(p>0,05)$. Juvenis foram registrados em todas as estações do ano e a reprodução ocorreu durante todo o ano. A estrutura populacional é similar ao modelo conhecido para eglídeos e os métodos de captura afetam a análise para A. georginae, onde os dados agrupados e as capturas por armadilha apresentaram maior abundância de indivíduos do que rede de mão e machos predominando nas classes de tamanho mais altas e fêmeas nas classes de tamanho intermediárias. Portanto, uma visão integrativa dos métodos de captura é o melhor modelo para estudar a dinâmica populacional de eglídeos.

Palvras-chave: comprimento da carapaça, distribuição de frequência, abundância relativa, período reprodutivo, eglídeos. 


\section{Introduction}

The genus Aegla Leach, 1820 is present in river basins in Southern Brazil, Uruguay, Argentina, Southern Bolivia, Paraguay, and South-central Chile, with 75 species currently described (Santos et al., 2014). The aeglids are the only anomurans inhabiting freshwater environments (lakes, streams, cave rivers, and current rivers; usually hidden under stones and plant debris), and most species are endemic with restricted distributions (Bond-Buckup et al., 2008). Aeglids can inhabit even Eichhornia crassipes roots in association with other benthic macroinvertebrates (Copatti et al., 2013).

The species with restricted distributions are vulnerable and may disappear before limnic studies can be performed. According to Bond-Buckup and Santos (2007), aeglids do not tolerate sudden environmental disturbances, which may lead to a reduction in or disappearance of their populations. Therefore, investigations focused on their populations can contribute to the assessment of the environmental status and to establish conservation measures.

Information about the population structure is important in working with decapods because the data assist in understanding the biology of the species in a given ecosystem. Population aspects in aeglids have been described by several authors in rivers located in the Atlantic Forest in Brazil such as Aegla paulensis Schmitt, 1942 (Lopez, 1965), Aegla perobae Hebling and Rodrigues 1977 (Rodrigues and Hebling, 1978), Aegla leptodactyla Buckup and Rossi, 1977 (Noro and Buckup, 2002), Aegla castro Schmitt, 1942 (Swiech-Ayoub and Masunari, 2001; Fransozo et al., 2003), Aegla longirostri Bond-Buckup and Buckup, 1994 (Colpo et al., 2005), Aegla franciscana Buckup and Rossi, 1977 (Gonçalves et al., 2006), Aegla schmitti Hobbs III, 1979 (Teodósio and Masunari, 2009), Aegla parana Schmitt, 1942 (Grabowski et al., 2013), Aegla platensis Schmitt, 1942 (Bueno and Bond-Buckup, 2000; Bueno et al., 2000; Dalosto et al., 2014), Aegla manuinflata Bond-Buckup and Santos, 2009 (Trevisan and Santos, 2014) and A. platensis, Aegla grisella BondBuckup and Buckup, 1994 and Aegla ludwigi Santos and Jara, 2013 (Copatti et al., 2015).

Usually, in studies of the population structure of aaeglids have not compared different capture methods, although Trevisan and Santos (2014) and Dalosto et al. (2014) have considered the capture methods in the evaluation of relative abundance of $A$. manuinflata and A. platensis, respectively. We agree that the capture methods influence the evaluation of the population structure of aeglids. So, the goal of this study is to evaluate the influence of different capture methods and the implication of these data in the analysis of population dynamics (size classes, relative abundance, sex-ratio, and reproductive periods) of Aegla georginae Santos and Jara, 2013, a newly described species (Santos et al., 2013) already categorized as "endangered" according to the IUCN (2013).

\section{Material and Methods}

\subsection{Study area}

Field investigations were conducted in the Perau River, Jaguari, RS, Brazil (29²9'13'S; 5442’42.6”W), a second order river located in the Jaguari River microbasin. The stretch of study is located on the southern boundary of the Atlantic Forest, a region of ecotone with the Pampa biome. The Jaguari River microbasin belongs to the Ibicuí River sub-basin, corresponding to the largest sub-basin of the Uruguay River. The Jaguari River has its mouth in the upper Ibicuí River, and its tributaries are fast streams, creating valleys with rocky outcrops (Copatti et al., 2009).

The margins of the study stretch shows remnants of the original deciduous forest interspersed with grass patches, with low anthropic use in the surrounding lands. The bottom is mainly stony, but also consists of sand, gravel, clay, and leaves. The river has an average width of $3 \mathrm{~m}$ and a depth of $15-45 \mathrm{~cm}$.

The physiochemical parameters of the water were measured monthly. Dissolved oxygen and temperature were measured on an YSI oximeter (model Y5512), $\mathrm{pH}$ was measured with the $\mathrm{pH}$ meter Quimis (model 400.A) and alkalinity, hardness, and total ammonia were monitored by a water analysis kit (Alfakit, Florianópolis, Brazil). The current velocity was calculated by the time taken for a float to cover a distance of $3 \mathrm{~m}$ (in triplicate).

\subsection{Field sampling}

Monthly samplings were performed from November 2007 to October 2008 in a section of the stream of approximately $32 \mathrm{~m}$ of length. The specimens were captured using two capture methods: 1) 25 plastic traps with beef liver randomly set along the sampling zone, and all traps were set late in the afternoon and checked for aeglid individuals the following morning and 2) a handnet (Surber sampler, $0.1 \mathrm{~m}^{2}$ area, $250 \mu \mathrm{m}$ mesh net) with an effort of $30 \mathrm{~min}$ by two researchers for each monthly sampling. The collection methods were adapted from Trevisan and Santos (2014).

The following body dimensions of individuals were measured with a digital caliper to the nearest $0.01 \mathrm{~mm}$ : carapace length (CL) (from the tip of the rostrum to the posterior margin of the carapace); carapace width (CW) (distance between the bases of the epibranchial spines); second abdominal somite width (AW); length of the major cheliped propodus (LMQ); length of the minor cheliped propodus (LSQ); and height of the major cheliped propodus (HMQ) (Figure 1). After the measurements, the specimens (alive) were returned to the collection location.

\subsection{Data analysis}

The specimens were sexed based on the presence (females) or absence (males) of pleopods. Individuals with a CL less than $7.01 \mathrm{~mm}$ were verified for the location of the genital openings (on the carpus of the third pair of pereiopods in females). Moreover, all ovigerous females were catalogued. Males and females with CL less than the smallest ovigerous females were categorized as juveniles, 


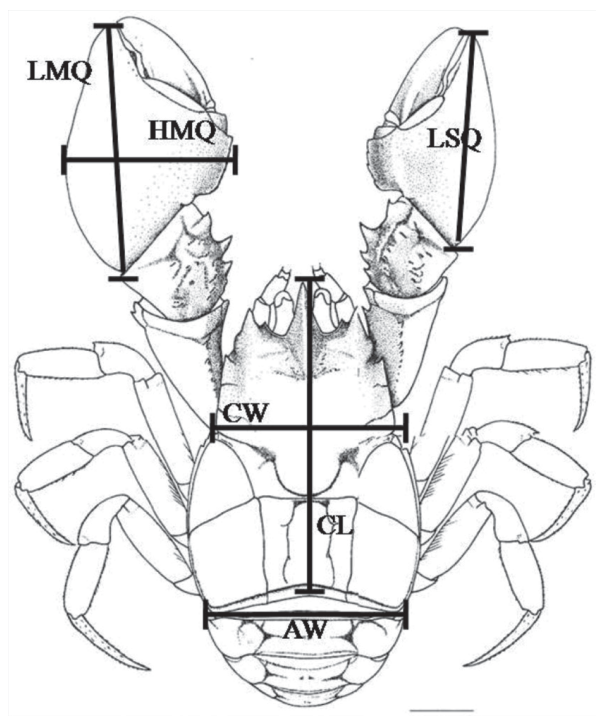

Figure 1. Aegla georginae body dimensions. CL: Carapace length; CW: Carapace width; AW: Second abdominal somite width; LSQ: Length of the minor cheliped propodus; LMQ: Length of the major cheliped propodus; HMQ: Height of the major cheliped propodus. Adapted from Santos et al. (2013).

i.e., sexually immature individuals entering the population according Grabowski et al. (2013).

To determine the frequency distribution of the size-classes, males and females were organized in classes. The interval was $1.0 \mathrm{~mm}$, corresponding to one-fourth of the standard deviation of the CL of all animals sampled (Markus, 1971).

The sex-ratio was evaluated monthly for each size-class of CL. For this parameter, we employed a Chi-squared test for expected proportions of 1:1 and a significance level of 5\% (Snedercor and Cochran, 1967). The reproductive period was evaluated through the presence of ovigerous females in each season of the year.

To calculate the mean $( \pm$ SEM) of the biometric measurements, size classes, and relative abundance to verify the influence of the capture method, three metrics were considered: 1) grouped data (date combined form handnet + trap); 2) only trap captures and; 3 ) only handnet captures. All data were tested for normality and heterocedasticity with the Shapiro-Wilk and Levene tests, respectively. A two-way analysis of variance (ANOVA) followed by Tukey's post hoc tests $(p<0.05)$ was performed on these values. All tests were performed in the BioEstat 5.0 software (Zar, 1996).

\section{Results}

We sampled 1774 individuals: 1259 males (21 and 97 juveniles and 1029 and 113 adults in trap and handnet, respectively), 512 females ( 05 and 140 juveniles, 184 and 64 adults, and 81 and 38 ovigerous in trap and handnet, respectively) and 03 unsexed individuals (02 and 01 in trap and handnet, respectively) (Table 1).
Table 1. Number of individuals of Aegla georginae collected during the four seasons in the Perau River, Ibicuí Basin, Brazil.

\begin{tabular}{lccccccc}
\hline \multirow{2}{*}{ Seasons } & JM & AM & JF & AF & OF & NS & Total \\
\cline { 2 - 8 } & \multicolumn{7}{c}{ TOTAL (TRAP $=$ HANDNET) } \\
\hline Spring & 32 & 259 & 32 & 80 & 02 & 01 & 406 \\
Summer & 18 & 328 & 14 & 126 & 00 & 00 & 486 \\
Autumn & 51 & 235 & 43 & 17 & 112 & 02 & 460 \\
Winter & 17 & 319 & 56 & 25 & 05 & 00 & 422 \\
Total & 118 & 1141 & 145 & 248 & 119 & 03 & 1774 \\
\hline \multicolumn{7}{c}{ TRAP } \\
\hline Spring & 03 & 216 & 00 & 59 & 00 & 00 & 278 \\
Summer & 04 & 318 & 01 & 109 & 00 & 00 & 432 \\
Autumn & 00 & 197 & 01 & 03 & 78 & 02 & 281 \\
Winter & 00 & 297 & 01 & 13 & 03 & 00 & 314 \\
Total & 21 & 1028 & 05 & 184 & 81 & 02 & 1321 \\
\hline & \multicolumn{7}{c}{ HANDNET } \\
\hline Spring & 29 & 43 & 32 & 21 & 02 & 01 & 128 \\
Summer & 14 & 10 & 13 & 17 & 00 & 00 & 54 \\
Autumn & 51 & 38 & 42 & 14 & 34 & 00 & 179 \\
Winter & 17 & 22 & 55 & 12 & 02 & 00 & 108 \\
Total & 97 & 113 & 140 & 64 & 38 & 01 & 453 \\
\hline
\end{tabular}

(JM) Juvenile males; (AM) adult males; (JF) juvenile females; (AF) adult females; (OF) ovigerous females; (NS) non-sexed juveniles.

Individuals less than $10.45 \mathrm{~mm}$ CL were considered to be juveniles based on the $\mathrm{CL}$ of the smallest ovigerous female sampled in the field. The CL of the males ranged between 3.11 and $26.00 \mathrm{~mm}$, whereas the CL of the females ranged from 3.73 to $22.36 \mathrm{~mm}$.

The mean size was significantly higher in males, considering the grouped dates (date combined form handnet + trap) and trap captures. Furthermore, the abundance of males was significantly higher than females for both methods. However, the analysis of handnet captures showed no significant difference between the mean size for males and females (Table 2).

In determining whether the relative abundance between males and females differed from the expected proportion of $1: 1$, we found that the data showed different results depending on the capture method. The relative abundance evaluated with the grouped dates was 2.45 males for each female, significantly different in all months of sampling. For trap captures, the relative abundance was also significantly higher with 3.91 males for each female, except in March of 2008 , when the expected ratio was similar. The handnet captures, showed a relative abundance of 0.8 males for each female, and this ratio followed the expected ratio in most months of sampling, except for February, May, and June of 2008, during which the relative abundance of females was statistically higher than that of the males (Figure 2A-C).

The frequency distribution of the size-classes of the sampled animals was bimodal for both male and female 

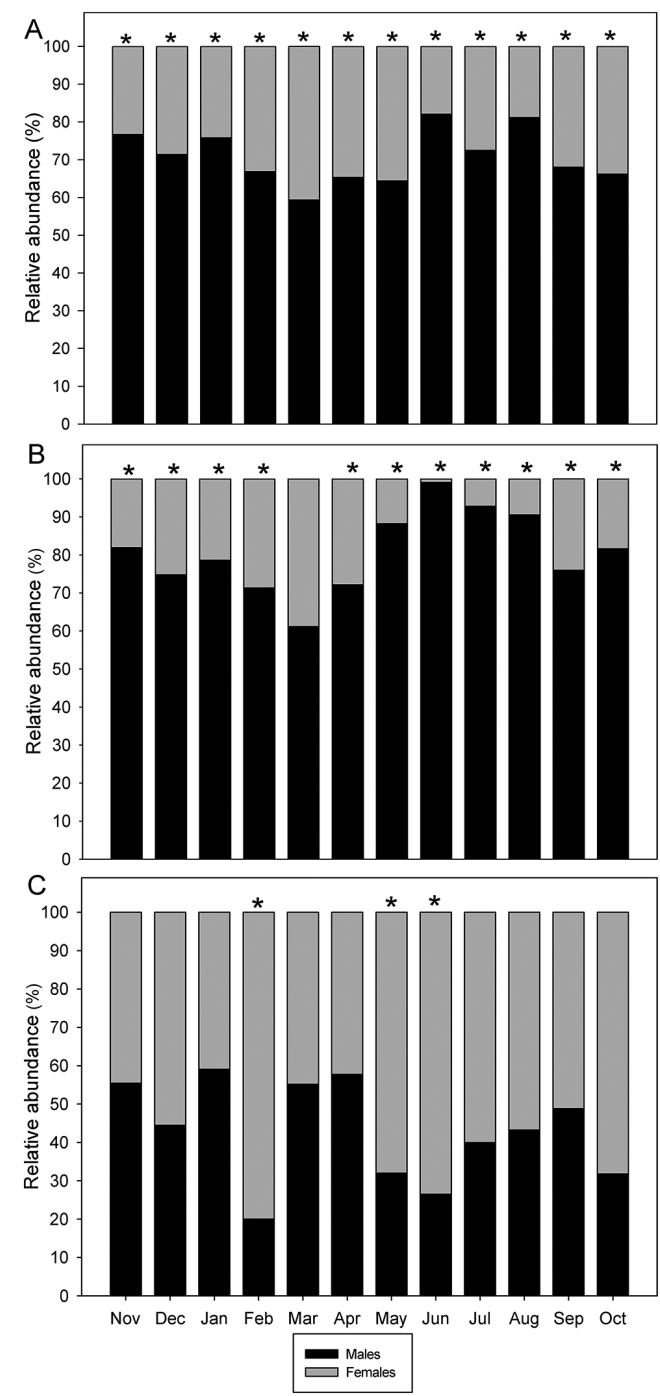

Figure 2. Relative abundance in males and females of Aegla georginae, Perau River, Ibicuí Basin, Brazil. A = Grouped dates; $\mathrm{B}=$ Captures only with trap; $\mathrm{C}=$ Captures only with handnet. * Significant difference between males and females.
A. georginae for grouped dates and trap captures. Two age groups were distinguishable in the size-class frequency. Regarding the sex-ratio within the CL size classes, males are prevailing in the larger classes, and females in the intermediary classes, with minimal differences in the lower classes for grouped dates and trap captures (Figure 3A, B). But, the handnet captures, found similarity between the number of males and females in all size classes (Figure 3C).

A total of 119 ovigerous females were captured (32.42\%) out of a total of 367 adult females. Ovigerous females occurred mainly in autumn, but also in winter and early spring. Ovigerous females did not occur in the summer. Juveniles occurred in all seasons (Figure 4).

Physiochemical parameters of water quality in the Perau River had lower temperatures in the winter and autumn, dissolved oxygen levels in the water above $6.00 \mathrm{mg} . \mathrm{L}^{-1}$ in all seasons of the year and $\mathrm{pH}$ near the neutral range (Table 3).

\section{Discussion}

The sampling site is a small stream with few shelters and the impact by human activities in the surrounding areas is low, without affect water quality (Brasil, 2005; Copatti et al., 2014), and consequently the survival of the aeglids populations (Bond-Buckup et al., 2008).

We show that differences in the results of the mean size between males and females were influenced by the capture method, where aeglids have significantly smaller sizes in the handnet captures in comparison with trap captures and grouped data (Table 2). The largest aeglid caught by handnet had a $19.61 \mathrm{~mm} \mathrm{CL}$, whereas the largest caught by trap had a $26.00 \mathrm{~mm}$ CL. Moreover, trap captures registered 283 males with CLs greater than $19.61 \mathrm{~mm}$. This number may be because of the effectiveness of trap captures in selecting larger males attracted by the bait of beef liver and preventing entry of smaller individuals. Males have documented aggressive behavior (Cohen et al., 2011; Palaoro et al., 2013; Trevisan et al., 2014). Females or juveniles would not enter the traps to avoid agonistic encounters with the larger males (Trevisan and Santos, 2014). Similar to this study, Dalosto et al. (2014) also

Table 2. Biometric measurements (mm) (mean \pm SEM) of Aegla georginae, Perau River, Ibicuí Basin, Brazil.

\begin{tabular}{|c|c|c|c|c|c|c|}
\hline \multirow{2}{*}{$\operatorname{Sex}$} & CL & $\mathbf{C W}$ & AW & LMQ & LSQ & HMQ \\
\hline & \multicolumn{6}{|c|}{ TOTAL } \\
\hline $\mathbf{M}$ & $16.61 \pm 0.47^{\mathrm{Aa}}$ & $10.62 \pm 0.30^{\mathrm{Aa}}$ & $10.72 \pm 0.30^{\mathrm{Aa}}$ & $10.18 \pm 0.29^{\mathrm{Aa}}$ & $8.76 \pm 0.25^{\mathrm{Aa}}$ & $6.71 \pm 0.19^{\mathrm{Aa}}$ \\
\hline \multirow[t]{2}{*}{$\mathbf{F}$} & $13.12 \pm 0.58^{\mathrm{Bb}}$ & $7.62 \pm 0.34^{\mathrm{Ab}}$ & $8.88 \pm 0.40^{\mathrm{Bb}}$ & $6.76 \pm 0.30^{\mathrm{Bb}}$ & $5.94 \pm 0.26^{\mathrm{Bb}}$ & $3.82 \pm 0.17^{\mathrm{Bb}}$ \\
\hline & \multicolumn{6}{|c|}{ TRAP } \\
\hline $\mathbf{M}$ & $17.72 \pm 0.55^{\text {Aa }}$ & $11.50 \pm 0.35^{\mathrm{Aa}}$ & $11.53 \pm 0.35^{\mathrm{Aa}}$ & $11.06 \pm 0.34^{\mathrm{Aa}}$ & $9.50 \pm 0.29^{\mathrm{Aa}}$ & $7.42 \pm 0.23^{\mathrm{Aa}}$ \\
\hline \multirow[t]{2}{*}{$\mathbf{F}$} & $16.08 \pm 0.97^{\mathrm{Ab}}$ & $9.36 \pm 0.57^{\mathrm{Ab}}$ & $11.10 \pm 0.67^{\mathrm{Ab}}$ & $8.52 \pm 0.52^{\mathrm{Bb}}$ & $7.40 \pm 0.45^{\mathrm{Bb}}$ & $4.88 \pm 0.30^{\mathrm{Ab}}$ \\
\hline & \multicolumn{6}{|c|}{ HANDNET } \\
\hline $\mathbf{M}$ & $10.22 \pm 0.72^{\mathrm{Ba}}$ & $5.96 \pm 0.42^{\mathrm{Ba}}$ & $6.46 \pm 0.46^{\mathrm{Ba}}$ & $5.12 \pm 0.36^{\mathrm{Ba}}$ & $4.53 \pm 0.32^{\mathrm{Ba}}$ & $2.83 \pm 0.20^{\mathrm{Ba}}$ \\
\hline $\mathbf{F}$ & $9.78 \pm 0.63^{\mathrm{Ca}}$ & $5.67 \pm 0.36^{\mathrm{Ba}}$ & $6.39 \pm 0.41^{\mathrm{Ca}}$ & $4.71 \pm 0.30^{\mathrm{Ba}}$ & $4.23 \pm 0.27^{\mathrm{Ba}}$ & $2.60 \pm 0.17^{\mathrm{Ca}}$ \\
\hline
\end{tabular}

$\mathrm{M}=$ Males; F = Females; CL: Carapace length; CW: Carapace width; AW: Second abdominal somite width; LMQ: Length of the major cheliped propodus; LSQ: Length of the minor cheliped propodus; HMQ: Height of the major cheliped propodus. Capital letters refer to differences between capture methods for the same sex. Lowercase letters refer to differences between the sexes for the same capture method. 
found that individuals were significantly greater in size in trap captures than in handnet captures.

Furthermore, sexual dimorphism, with males larger than females (CL, CW, AW, LSQ, LMQ, and HMQ), was verified for grouped data and trap captures, but not for handnet capture (Table 2). Other studies on the size of male and female aeglids are also possibly influenced by the capture method (Table 4), which demonstrates the importance of considering the capture method in the evaluation of sexual dimorphism. Similar to this current
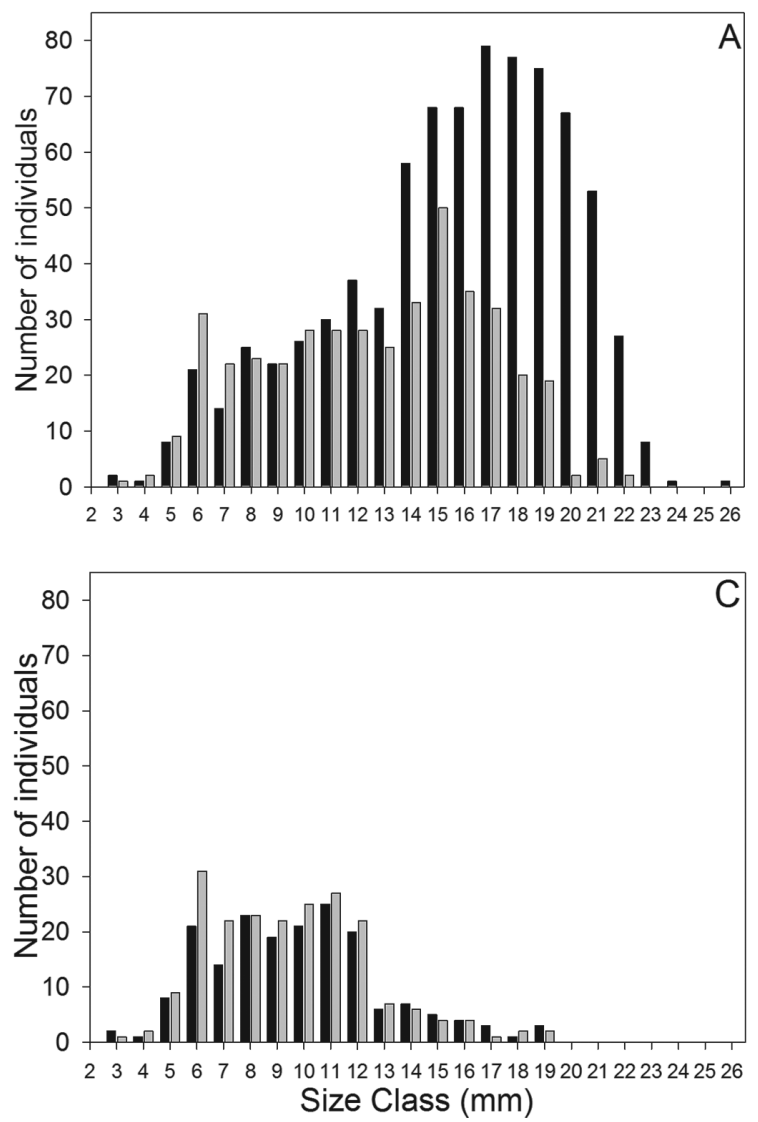

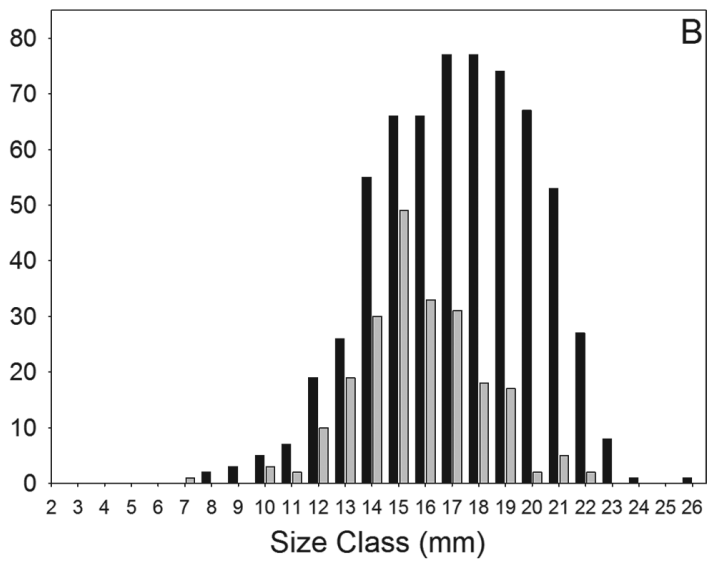

Males

Females

Figure 3. Distribution of the size class of the carapace length of males and females of Aegla georginae, Perau River, Ibicuí Basin, Brazil. A = Grouped dates; $\mathrm{B}=$ Captures only with trap; $\mathrm{C}=$ Captures only with handnet.

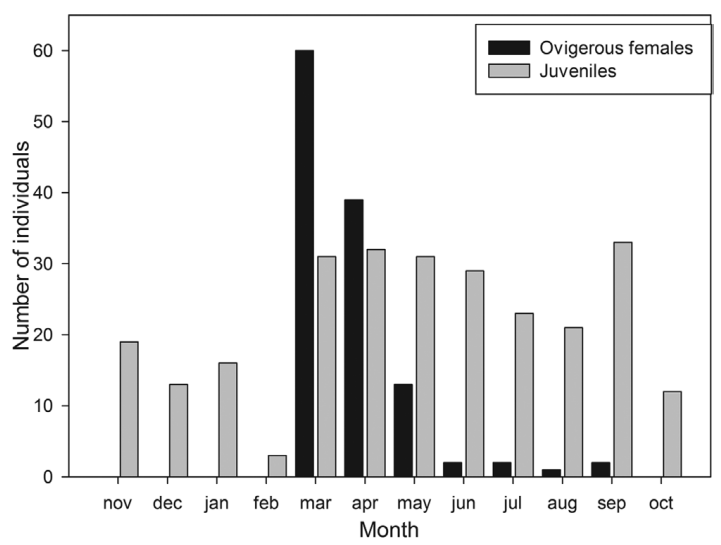

Figure 4. Number of juveniles and ovigerous females of Aegla georginae sampled in the four seasons of the year, Perau River, Ibicuí Basin, Brazil. Different letters indicate significant differences between seasons of the year.
Table 3. Physiochemical parameters of water quality in the Perau River, Ibicuí Basin, Brazil.

\begin{tabular}{lcccc}
\hline \multicolumn{1}{c}{ Parameters } & Spring & Summer & Autumn & Winter \\
\hline $\begin{array}{l}\text { Ammonia } \\
\left(\mathrm{mg} . \mathrm{L}^{-1} \mathrm{NH}_{3}\right)\end{array}$ & 0.01 & 0.01 & 0.01 & 0.01 \\
$\mathrm{pH}$ & 6.50 & 7.50 & 6.00 & 6.50 \\
$\begin{array}{l}\text { Alkalinity } \\
\left(\mathrm{mg} . \mathrm{L}^{-1} \mathrm{CaCO}_{3}\right)\end{array}$ & 15.00 & 16.00 & 15.00 & 20.00 \\
$\begin{array}{l}\text { Hardness } \\
\left(\mathrm{mg} . \mathrm{L}^{-1} \mathrm{CaCO}_{3}\right)\end{array}$ & 25.00 & 30.00 & 30.00 & 35.00 \\
$\begin{array}{l}\text { Temperature } \\
\left({ }^{\circ} \mathrm{C}\right)\end{array}$ & 15.00 & 21.50 & 11.00 & 11.50 \\
$\begin{array}{l}\text { Dissolved } \\
\begin{array}{l}\text { Oxygen } \\
\left(\mathrm{mg} . \mathrm{L}^{-1} \mathrm{O}_{2}\right)\end{array}\end{array}$ & 6.25 & 8.55 & 6.75 & 6.00 \\
$\begin{array}{l}\text { Current velocity } \\
\left(\mathrm{m} . \mathrm{s}^{-1}\right)\end{array}$ & 0.32 & 0.25 & 0.33 & 0.24 \\
\hline & & & & \\
\hline
\end{tabular}


Table 4. Sexual and sampling method from published studies on Brazilian species of Aegla.

\begin{tabular}{cccc}
\hline Species & Sampling method & Sexual dimorphism & Authors \\
\hline A. castro & Handnet & Males $>$ Females & Swiech-Ayoub and Masunari (2001) \\
A. castro & Handnet & Absent & Fransozo et al. (2003) \\
A. paulensis & Handnet & Males $>$ Females & Lopez (1965) \\
A. franciscana & Handnet & Males $>$ Females & Gonçalves et al. (2006) \\
A. georginae & Trap & Males $>$ Females & Currente study \\
A. georginae & Handnet & Absent & Currente study \\
A. grisella & Trap + Handnet & Males $>$ Females & Copatti et al. (2015) \\
A. leptodactyla & Handnet & Males $>$ Females & Noro and Buckup (2002) \\
A. longirostri & Handnet & Males $>$ Females & Colpo et al. (2005) \\
A. ludwigi & Trap + Handnet & Males $>$ Females & Copatti et al. (2015) \\
A. manuinflata & Trap + Handnet & Males $>$ Females & Trevisan and Santos (2014) \\
A. parana & Trap & Males $>$ Females & Grabowski et al. (2013) \\
A. perobae & Handnet & Males $>$ Females & Rodrigues and Hebling (1978) \\
A. platensis & Handnet & Females $>$ Males & Bueno and Bond-Buckup (2000) \\
A. platensis & Trap & Males $>$ Females & Dalosto et al. (2014) \\
A. platensis & Handnet & Females $>$ Males & Dalosto et al. (2014) \\
A. platensis & Trap + Handnet & Males $>$ Females & Copatti et al. (2015) \\
A. schmitti & Trap + Handnet & Males $>$ Females & Teodósio and Masunari (2009) \\
\hline & & &
\end{tabular}

study, Dalosto et al. (2014) compared the use of traps with handnets and also found that the males were significantly greater in size than the females only in the trap captures.

The mortality and the differential behavior are several factors that may act differently in males and females, determining the preponderance of one sex in the population (Noro and Buckup, 2002). The smaller size of females may be because of the molt increment or an increase in the intermolt period during the reproductive period, caused by nutritional deficiencies and stress because of posture (Swiech-Ayoub and Masunari, 2001). Markedly, the larger size of the males can be related to a differential growth rate between sexes. Whereas females direct a significant portion of energy to the events of reproduction, the growth rate of males is not reduced in this period (Diaz and Conde, 1989).

Markedly, trap captures (or grouped dates) may underestimate the presence of females in the population and generate erroneous data for the relative abundance. This phenomenon was verified in the current study. However, the relative abundance in handnet captures was 0.8 males:females (Figure 2), a similar proportion to the expected 1:1. However, the reported ratio had a greater abundance of ovigerous females and juveniles with a few large males.

Trevisan and Santos (2014) and Dalosto et al. (2014) also analyzed capture methods in the assessment of the relative abundance for A. manuinflata and A. platensis, respectively. Differences according to capture method were found by Trevisan and Santos (2014), but not by Dalosto et al. (2014). Other studies using handnets or even manual efforts in capturing aeglids also found a relative abundance of 1:1 for $A$. paulensis, A platensis, A. leptodactyla, A castro, A. longirostri, and A. franciscana (López, 1965; Bueno and Bond-Buckup, 2000; Noro and Buckup, 2002; Fransozo et al., 2003; Colpo et al., 2005; Gonçalves et al., 2006, respectively). The handnet captures is more appropriate for the assessment of the relative abundance, and trap captures allows the recovery of larger animals.

The population structure was bimodal with two age groups distinguishable in the size-class frequency distribution for both sexes (except in handnet captures) (Figure 3). The bimodality or polimodality in the size frequency distribution might be an indicator of intra and interspecific environmental factors such as recruitment peaks, differential catastrophic mortality between the sexes or even ethological differences (Diaz and Conde, 1989). This result agrees with information for other aeglids: A. longirotri, A. franciascana, A. platensis, and A. manuinflata (Colpo et al., 2005; Gonçalves et al., 2006; Dalosto et al., 2014; Trevisan and Santos, 2014, respectively), demonstrating that bimodality may be a common phenomenon for aeglids, where males are predominate in the larger classes, and females in the intermediary classes.

A lower number of ovigerous females $(32.42 \%)$ than non-ovigerous was recorded during the study period. Other studies investigating aeglids support this pattern (Noro and Buckup, 2002; Fransozo et al., 2003; Gonçalves et al., 2006; Teodósio and Masunari, 2009; Trevisan and Santos, 2014; Copatti et al., 2015). This finding may be associated with reproductive strategies because ovigerous females seek protected habitats with low currents and near riverbanks, reducing their sampling (Bueno and Bond-Buckup, 2000).

Ovigerous female $A$. georginae were found in greater abundance in autumn (march, april and may) (Figure 4), indicating a likely peak for this season. Similar results were observed for A. leptodactyla, A. franciscana, A. franca, A. parana, and A. manuinflata (Noro and 
Buckup, 2002; Gonçalves et al., 2006; Bueno and Shimizu, 2008; Grabowski et al., 2013; Trevisan and Santos, 2014, respectively). The absence of females in the late spring and summer indicates that reproduction probably does not occur in the warmer months of the year.

Local climatic conditions can influence life cycle of crustaceans (Frigotto et al., 2013). Bueno and Shimizu (2008) performed an extensive revision of the factors responsible for the interspecific variation on the reproductive period of aeglids and suggest that the reproductive period tends to be concentrated in the colder months of the year at lower latitudes, as is the case in the present study. Besides, subtropical regions have seasonal changes in rainfall and induce physical and chemical changes in water (Figueredo and Giani, 2001; Bartozek et al., 2014) that may contribute to this pattern.

Juveniles were recorded during all months of sampling, even in months with no record of ovigerous females (Figure 4), indicating that they might have originated from spawning that occurred in previous months (autumn, winter and early spring). Colpo et al. (2005) and Dalosto et al. (2014) also observed this pattern for A. longirostri and A. platensis. According to Teodósio and Masunari (2009), the peak breeding in the cold months is a strategy that allows juveniles to use the most abundant resources in spring and summer.

In general, the population structure agrees with the known pattern for aeglids, presenting sexual dimorphism (larger males), a bimodal distribution of the size-class frequencies and reproduction with peaks in the cold months. We demonstrate that the capture methods clearly influence the effectiveness of the analysis of $A$. georginae, notably in the relative abundance between males and females. Although no consensus on a best single sampling method is available, making difficult the comparisons between population studies of aeglids, the importance of the capture method must be considered in evaluating the results. Using both capture methods (trap + handnet) provides an integrated view and therefore is the best model for the study of the population dynamics of aeglids.

\section{Acknowledgements}

We would like to thank $\mathrm{CNPq}$ for the productivity grant for Sandro Santos (308598/2011-3).

\section{References}

BARTOZEK, E.C.R., BUENO, N.C. and RODRIGUES, L.C., 2014. Influence of fish farming in net cages on phytoplankton structure: a case study in a subtropical Brazilian reservoir. Brazilian Journal of Biology $=$ Revista Brasileira de Biologia, vol. 74, no. 1, pp. 145-155. http://dx.doi.org/10.1590/1519-6984.21912. PMid:25055096.

BOND-BUCKUP, G. and SANTOS, S., 2007. Crustáceos anomuros de águas continentais: diversidade e aspectos biológicos. Ciência e Ambiente, vol. 35, no. 1, pp. 47-54.
BOND-BUCKUP, G., JARA, C.J., PÉREZ-LOSADA, M., BUCKUP, L. and CRANDALL, K.A., 2008. Global diversity of crabs (Aeglidae: Anomura: Decapoda) in freshwater. Hydrobiology, vol. 595, no. 1, pp. 267-273. http://dx.doi.org/101007/s10750007-9022-4.

BRASIL. Conselho Nacional do Meio Ambiente - CONAMA, 2005. Resolução n. 357, de 17 de março de 2005 do Conselho Nacional do Meio Ambiente. Diário Oficial da República Federativa do Brasil, Brasília, 18 mar. 2005, Seção 1, no. 53, pp. 58-63.

BUENO, A.A.P. and BOND-BUCKUP, G., 2000. Dinâmica populacional de Aegla platensis Schmitt (Crustacea, Decapoda, Aeglidae). Revista Brasileira de Zoologia, vol. 17, no. 1, pp. 43-49.. http://dx.doi.org/10.1590/S0101-81752000000100005.

BUENO, A.A.P., BOND-BUCKUP, G. and BUCKUP, L., 2000. The growth of Aegla platensis Schmitt (Crustacea, Decapoda, Aeglidae) in natural habitat. Revista Brasileira de Zoologia, vol. 17, no. 1, pp. 51-60. http://dx.doi.org/10.1590/S0101-81752000000100006.

BUENO, S.L.S. and SHIMIZU, R.M., 2008. Reproductive biology and functional maturity in females of Aegla franca (Decapoda: Anomura: Aeglidae). Journal of Crustacean Biology, vol. 28, no. 4, pp. 652-662.. http://dx.doi.org/10.1651/07-2974.1.

COHEN, F.P.A., TAKANO, B.F., SHIMIZU, R.M. and BUENO, S.L.S., 2011. Life cycle and population structure of Aegla paulensis (Decapoda: Anomura: Aeglidae). Journal of Crustacean Biology, vol. 31, no. 3, pp. 389-395.. http://dx.doi.org/10.1651/10-3415.1.

COLPO, K.D., RIBEIRO, L.D. and SANTOS, S., 2005. Population biology of the freshwater Anomura Aegla longirostri (Aeglidae) from South Brazilian streams. Journal of Crustacean Biology, vol. 25, no. 3, pp. 495-499.. http://dx.doi.org/10.1651/C-2543.

COPATTI, C.E., FAGUNDES, L.S., QUAINI, J.B. and COPATTI, B.R., 2013. Diversity of aquatic arthropods on Eichhornia crassipes (Mart.) Solms roots before and after removal of substrate in a reservoir in southern Brazil. Pan-American Journal of Aquatic Sciences, vol. 8, no. 4, pp. 265-275.

COPATTI, C.E., MACHADO, J.V.V. and TREVISAN, A., 2015. Morphological variation in the sexual maturity of three sympatric aaeglids in a river in southern Brazil. Journal of Crustacean Biology, vol. 35, no. 1, pp. 59-67. http://dx.doi. org/10.1163/1937240X-00002303.

COPATTI, C.E., MOREIRA, T.B. and MENZEL, C.A., 2014. Avaliação da qualidade ambiental de uma microbacia no sul do Brasil através de diferentes abordagens. Ambiência, vol. 10, no. 2, pp. 511-526. http://dx.doi.org/10.5935/ambiencia.2014.02.06.

COPATTI, C.E., ZANINI, L.G. and VALENTE, A., 2009. Ictiofauna da microbacia do Rio Jaguari - Jaguari/RS. Biota Neotropica, vol. 9, no. 2, pp. 179-186. http://dx.doi.org/10.1590/ S1676-06032009000200017.

DALOSTO, M.M., PALAORO, A.V., OLIVEIRA, D., SAMUELSSON, E. and SANTOS, S., 2014. Population biology of Aegla platensis (Decapoda: Anomura: Aeglidae) in a tributary of the Uruguay River, state of Rio Grande do Sul, Brazil. Zoologia, vol. 31, no. 3, pp. 215-222.. http://dx.doi.org/10.1590/S1984-46702014000300002.

DIAZ, H. and CONDE, J.E., 1989. Population dynamics and life of mangrove crab Aratus pisonii (Brachyura, Grapsidae) in a marine environment. Bulletin of Marine Science, vol. 45, no. 1, pp. 148-163.

FIGUEREDO, C.C. and GIANI, A., 2001. Seasonal variation in the diversity and species richness of phytoplankton in a tropical 
eutrophic reservoir. Hydrobiologia, vol. 445, no. 1-3, pp. 165-174. http://dx.doi.org/10.1023/A:1017513731393.

FRANSOZO, A., COSTA, R.C., REIGADA, A.L.D. and NAKAGAKI, J.M., 2003. Population structure of Aegla castro Schmitt, 1942 (Crustacea: Anomura: Aeglidae) from Itatinga (SP), Brazil. Acta Limnologica Brasiliensia, vol. 15, no. 1, pp. 13-20. http://dx.doi.org/101590/S1984-46702009000100004

FRIGOTTO, S.F., MAROCHI, M.Z. and MASUNARI, S., 2013. Relative growth of Acantholobulus schmitti (Rathbun, 1930) (Crustacea, Brachyura, Panopeidae) at Guaratuba bay, southern Brazil. Brazilian Journal of Biology $=$ Revista Brasileira de Biologia, vol. 73, no. 4, pp. 863-870. http://dx.doi.org/10.1590/ S1519-69842013000400024. PMid:24789404.

GONÇALVES, R.S., CASTIGLIONI, D.S. and BOND-BUCKUP, G., 2006. Ecologia populacional de Aegla franciscana (Crustacea, Decapoda, Anomura) em São Francisco de Paula, RS, Brasil. Iheringia, Série Zoologia, vol. 96, no. 1, pp. 109-114. http:// dx.doi.org/101590/S0073-47212006000100019.

GRABOWSKI, R.C., SANTOS, S. and CASTILHO, A.L., 2013. Reproductive ecology and size of sexual maturity in the anomuran crab Aegla parana (Decapoda: Aeglidae). Journal of Crustacean Biology, vol. 33, no. 3, pp. 332-338. http://dx.doi. org/10.1163/1937240X-00002148.

INTERNATIONAL UNION FOR CONSERVATION OF NATURE - IUCN, 2013. IUCN red list categories: version 31. Cambridge: IUCN. 32 p.

LOPEZ, M.T., 1965. Estúdos biológicos en Aegla odebrechtii paulensis Schmitt. Boletim de Zoologia da Faculdade de Filosofia. Ciências e Letras da USP, vol. 25, pp. 301-314.

MARKUS, R., 1971. Elementos de estatística aplicada. Porto Alegre: UFRGS. 329 p.

NORO, C.K. and BUCKUP, L., 2002. Biologia reprodutiva e ecologia de Aegla leptodactyla Buckup \& Rossi, 1977 (Crustacea, Anomura, Aeglidae). Revista Brasileira de Zoologia, vol. 19, no. 4, pp. 1063-1074.. http://dx.doi.org/10.1590/S010181752002000400011

PALAORO, A.V., AYRES-PERES, L. and SANTOS, S., 2013. Modulation of male aggressiveness through different communication pathways. Behavioral Ecology and Sociobiology, vol. 67, no. 2, pp. 283-292.. http://dx.doi.org/10.1007/s00265-012-1448-7.
RODRIGUES, W. and HEBLING, N.J., 1978. Estudos biológicos em Aegla perobae Hebling \& Rodrigues, 1977 (Decapoda, Anomura) Rio de Janeiro. Brazilian Journal of Biology $=$ Revista Brasileira de Biologia, vol. 38, no. 2, pp. 383-390.

SANTOS, S., BUCKUP, G.B., BUCKUP, L., GONÇALVES, A.S., LOUREIRO, T.G., VERDI, A., SCARABINO, F. and CLAVIJO, C., 2014. Aeglidae (decapoda, anomura) from uruguay, wth description of a new species of Aegla. Crustaceana monographs, vol. 19 , no. 1 , pp. 195-205.

SANTOS, S., JARA, C.G., BARTHOLOMEI-SANTOS, M.L., PÉREZ-LOSADA, M. and CRANDALL, K.A., 2013. New species and records of the genus Aegla Leach, 1820 (Crustacea, Anomura, Aeglidae) from the West-Central region of Rio Grande do Sul, Brazil. Nauplius, vol. 21, no. 2, pp. 211-223. http://dx.doi. org/10.1590/S0104-64972013000200008.

SNEDERCOR, G.W. and COCHRAN, W.G., 1967. Statistical methods. 6th ed. Ames: Iowa State University Press. 593 p.

SWIECH-AYOUB, B.P. and MASUNARI, S., 2001. Flutuações temporal e espacial de abundância e composição de tamanho de Aegla castro Schmitt (Crustacea, Anomura, Aeglidae) no Buraco do Padre, Ponta Grossa, Paraná, Brasil. Revista Brasileira de Zoologia, vol. 18, no. 3, pp. 1003-1017.. http://dx.doi.org/10.1590/ S0101-81752001000300032.

TEODÓSIO, E.A.O. and MASUNARI, S., 2009. Estrutura populacional de Aegla schmitti (Crustacea: Anomura: Aeglidae) nos reservatórios dos Mananciais da Serra, Piraquara, Paraná, Brasil. Zoologia, vol. 26, no. 1, pp. 19-24.. http://dx.doi.org/10.1590/ S1984-46702009000100004.

TREVISAN, A. and SANTOS, S., 2014. Population dynamics of Aegla manuinflata Bond-Buckup and Santos 2009 (Decapoda: Aeglidae), an threatened species. Acta Limnologica Brasileira, vol. 26, no. 2, pp. 154-162. http://dx.doi.org/101590/S2179$975 \times 2014000200006$

TREVISAN, A., MAROCHI, M.Z. and MASUNARI, S., 2014. Circadian rhythm in males of Aegla schmitti (Decapoda, Anomura, Aeglidae) under laboratory conditions. Biological Rhythm Research, vol. 45, no. 5, pp. 803-816. http://dx.doi. org/101080/092910162014921410

ZAR, J.H., 1996. Biostatistical analysis. 3rd ed. New Jersey: Prentice-Hall. 662 p. 